\title{
Efficient Residential Buildings in Hot and Humid Regions: The Case of Abu Dhabi, UAE
}

\author{
Ayesha AlQubaisi, Ali Al-Alili* \\ Department of Mechanical Engineering, Khalifa University, Sas Al Nakhl Campus, Abu Dhabi, UAE
}

\begin{abstract}
The design, construction, and operation of highly efficient residential buildings in hot and humid climates represent a unique challenge for architects, contractors, and building owners. In this paper, a case study on the performance of a residential building located in hot and humid region is presented. The building is a single-family house, which is modeled as a multi-zone building. The transient systems simulation program (TRNSYS) is used to simulate the building under Abu Dhabi's typical meteorological year conditions. The main objective of this paper is to investigate the effects of applying different standards and building codes such as LEED, ASHRAE and Estidama for hot and humid regions on the energy performance of the building. The energy consumption of the building includes different equipment namely: air conditioners, lighting and electric water heaters. The building thermal analysis is extended to include the occupants thermal comfort analysis using different building codes. Moreover, the environmental impacts upon selecting Estidama for hot and humid regions will be discussed.
\end{abstract}

Keywords: Green building rating; Estidama; LEED; Energy Efficiency; Thermal comfort

\section{Introduction}

As the global population grows, the demand for energy also increases. In developed countries, buildings accounts for 20 $40 \%$ of total energy use [1]. Green buildings concept has gained a lot of interest over the past few years. Green buildings have lower energy consumption compared to that of the conventional ones. Recent studies on green buildings mostly focus on improving the design of the roof [2-4], insulation [5, 6], implementing solar systems such as multifunctional PV/T/D system for green building roofs [7] or analyzing facades material effectivness [8-10]. Moreover, these studies focused on analyzing the performance of the green buildings in coldmoderate climate and limited studies were conducted for hothumid climates. It is important to highlight and understand some issues that relate to the design of the building in hot and humid climate such as thermal comfort, energy consumption, and sustainability. Thermal comfort is the most neglected aspect in building design. Interestingly, based on the surveys that are performed every year for the U.S. occupants, one every three occupants shows dissatisfaction with the indoor temperature [11]. Therefore, achieving the target of providing comfort is very challenging for most engineers and HVAC designers, especially in hot and humid regions. Moreover, the energy consumption of the building should be taken into consideration by utilizing a suitable rating system. The United Arab Emirates is an example of a hot and humid country in which the highest typical temperature and humidity, derived from Typical Meteorological Year 2 (TMY2) weather data, can reach $450 \mathrm{C}$ and $85 \%$, respectively [12]. Dubai city in U.A.E has implemented Leadership in Energy and Environmental Design (LEED) codes in many of its buildings design and over 500 projects in the U.A.E have applied for LEED rating [13]. However, another rating system has been introduced recently in Abu Dhabi namely, Estidama [14], which means Sustainable in Arabic, was developed by the Abu Dhabi Urban Planning Council and was launched in April 2010.

The main concern with applying these standards and building rating systems is their effectiveness in satisfying the energy and comfort of the occupants in the buildings. It is also interesting to investigate the consequences of applying those international

${ }^{*}$ Corresponding author. Tel.: +971 (0)2 6075722

Fax: +971 (0)2607 5200; E-mail: alialalili@pi.ac.ae

(C) 2018 International Association for Sharing Knowledge and Sustainability

DOI: $10.5383 /$ ijtee.17.01.004 
standards on the energy consumption of the building as well as human comfort, taking into account the climate differences.

Newsham et al. [15] analyzed the energy performance of 100 LEED-certified commercial and institutional buildings and compare it to the general US commercial building stock. The results revealed that, on average, LEED buildings used 18-39\% less energy per floor area than their conventional counterparts. However, it was also reported that $28 \%$ - $35 \%$ of LEED certified buildings consumes more energy than their conventional counterparts

Ruveyda et al. [16] studied the applicability of LEED's energy and atmosphere category in three developing countries in India, Abu Dhabi and Turkey. It showed that India and Turkey have adopted LEED system but with some modifications to accommodate for the regional difference and Abu Dhabi has developed its building rating system called Estidama. However, according to the literature review that Ruveyda et al. [16] provided, applying LEED rating system is not always a promising option for energy reduction. Therefore, careful selection of an appropriate rating system is required.

Recently, Awadh [17] differentiated between the Green Building Rating Systems (GBRS) as an environmental-oriented tools from the Sustainability Assessment Systems, which are defined by three sustainability pillars; environmental, social and economic. Therefore, achieving a green building certification does not necessarily mean that the building succeeds in achieving its environmental targets. Awadh also provided a detailed comparison of sustainability pillar between internationally systems, GBRS, LEED and BREEAM, and two rating systems particularly developed for the gulf region, Estidama and Global Sustainability Assessment System (GSAS). Moreover, the study provides a qualitative discussion on the credit weighting given by these systems, focusing on energy and water criteria.

Moreover, Iman et al. [18] have analyzed the energy and economic benefits of refurbishing four existing villas in the United Arab Emirates (UAE) that were built between 1980s and 2010s. The refurbishment configuration used Estidama green building rating system and it was reported that, the most energyefficient-savings corresponded to upgrading wall insulation (20.8\% saving), followed by upgrading the roof insulation (up to $11.6 \%$ savings) and lastly, replacing the glazing which contributed to $3.2 \%$ savings only.

It is important to not only investigate the effect of applying building rating systems on the building's energy consumption, but also to understand the effect of these rating systems on its occupants. Therefore, this paper will analyze the energy performance and thermal comfort of a single-family house under four different building performance scenarios which are Estidama, LEED, and ASHRAE 90.2 as well a base case as built specifications. Thermal comfort analysis is carried out to determine the sensation of the occupant to the indoor conditions specified. This paper analysis was carried out using Google SketchUpTM and the transient systems simulation program (TRNSYS).

\section{Building Description}

\subsection{Location}

The selected base case is located in Abu Dhabi, United Arab Emirates $\left(24.5^{\circ}\right.$ north, $54.4^{\circ}$ east). The temperature range in Abu Dhabi, based on TMY2 weather data [12], peaks during July and August while, it is the lowest during January, Figure 1. Abu Dhabi has 6,726 Cooling Degree Days (CDD) at $10 \mathrm{oC}$ for an average of 5 years [19]. According to ASHRAE 90.1-2013 definition for international climate zone (Table 1), UAE is considered to fall within Zone 1A. Therefore, the work presented in this paper can be used for other locations with similar climate zones.

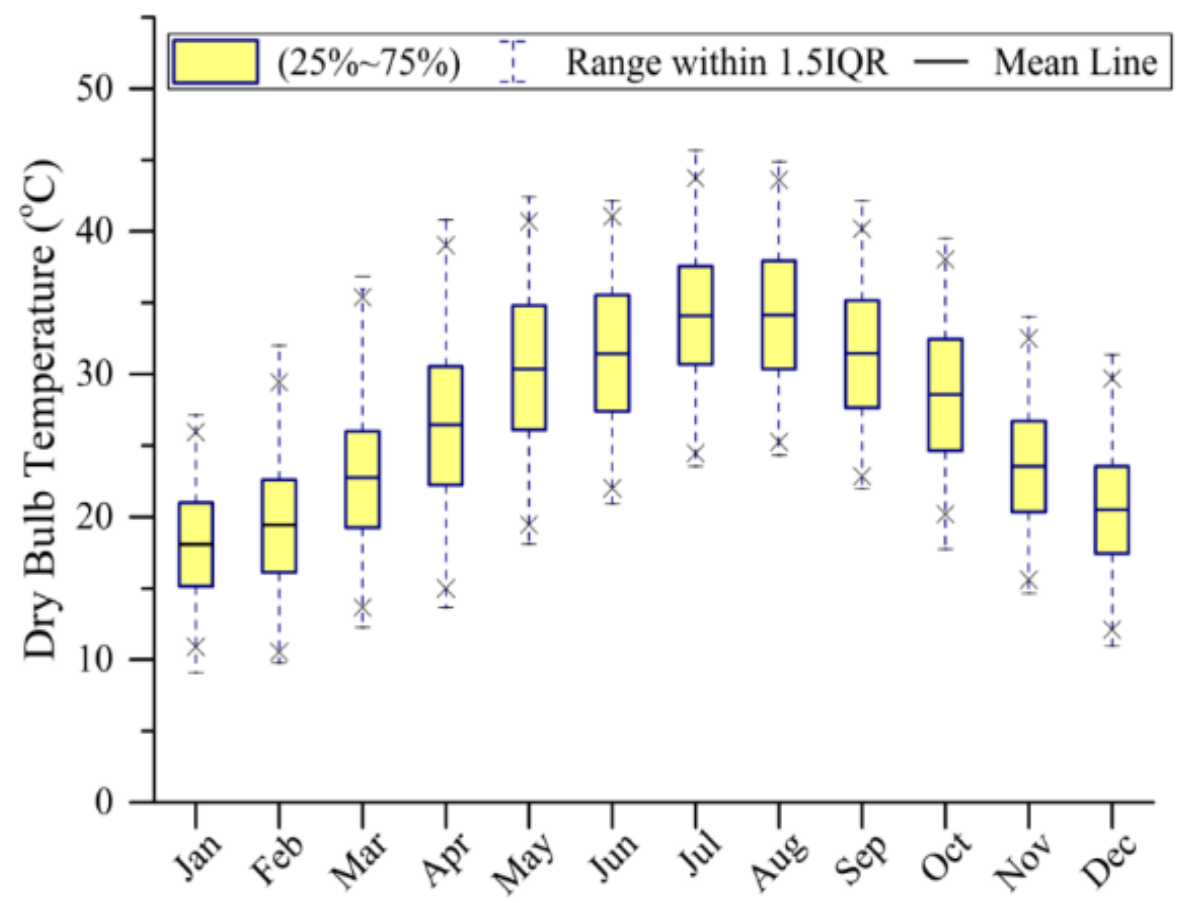

Figure 1. Monthly dry bulb temperature distribution for Abu Dhabi (based on TMY2 data [12]). 
Table 1. International Climate Zone Definitions based on ASHRAE 90.1-2013

\begin{tabular}{ccc}
\hline Zone number & Name & $\begin{array}{c}\text { Thermal Criteria } \\
(\text { SI) units }\end{array}$ \\
\hline \hline 1A and 1B & Very Hot -Humid & $5000<\mathrm{CDD} 10^{\circ} \mathrm{C}$ \\
& $(1 \mathrm{~A})$ & \\
& Dry (1B) & \\
2A and 2B & Hot-Humid (2A) & $3500<\mathrm{CDD} 10^{\circ} \mathrm{C}$ \\
& Dry (2B) & $\leq 5000$ \\
\hline
\end{tabular}

The goal of Estidama is to reduce energy consumption and according to UAE climate conditions, an indoor temperature of $24^{\circ} \mathrm{C}$ was selected for the simulated cases presented in this work.

\subsection{Specifications}

The base-case study is a typical 1-story villa in Abu Dhabi, which doesn't apply any building code requirements. It consists of four bedrooms, maid room, majlis (guest room), hall (living area), and unconditioned places such as toilets, baths, laundry room, and storage room. A detailed description of the villa and its building's material are shown in Table 2. The areas of the building elements with their respective orientations are shown in Table 3.

Table 2. Base case villa description

\begin{tabular}{cc}
\hline Parameters & Specifications \\
\hline \hline Num. of Floors & 1 \\
Total gross area & $506 \mathrm{~m}^{2}$ \\
Floor Height & $3.8 \mathrm{~m}$ \\
External wall & $15 \mathrm{~mm}$ mortar (outer surface) \\
& $200 \mathrm{~mm}$ concrete block \\
& $20 \mathrm{~mm}$ gypsum plaster \\
Roof & $140 \mathrm{~mm}$ gravel (outer surface) \\
& 2 mm bitumen \\
& $50 \mathrm{~mm}$ polystyrene \\
& $200 \mathrm{~mm}$ concrete slab \\
Fenestration & Single glazing, operable, metal framed \\
& windows \\
HVAC & (9) Split systems \\
Lighting & (61) 100 W Ceiling light \\
temperature & (16) $2 \times 40$ W Fluorescent tube light \\
& (7) Fluorescent tube mirror light \\
&
\end{tabular}

Table 3. Building elements area and orientation

\begin{tabular}{|c|c|c|}
\hline $\begin{array}{l}\text { Building } \\
\text { component }\end{array}$ & Orientation (Value and unit) & Total Area \\
\hline $\begin{array}{l}\text { Exterior } \\
\text { walls area }\end{array}$ & $\begin{array}{l}\text { South walls }\left(155 \mathrm{~m}^{2}\right) \\
\text { West walls }\left(65 \mathrm{~m}^{2}\right) \\
\text { North walls }\left(86 \mathrm{~m}^{2}\right) \\
\text { East walls }\left(68 \mathrm{~m}^{2}\right)\end{array}$ & $374 \mathrm{~m}^{2}$ \\
\hline $\begin{array}{l}\text { Windows } \\
\text { area }\end{array}$ & $\begin{array}{l}\text { South windows }\left(22 \mathrm{~m}^{2}\right) \\
\text { West windows }\left(11 \mathrm{~m}^{2}\right) \\
\text { North windows }\left(10 \mathrm{~m}^{2}\right) \\
\text { East windows }\left(8 \mathrm{~m}^{2}\right)\end{array}$ & $51 \mathrm{~m}^{2}$ \\
\hline Roof area & - & $506 \mathrm{~m}^{2}$ \\
\hline
\end{tabular}

\section{Simulation}

The base-case villa was sketched using Google SketchUpTM software as shown in Figure 2. A TRNSYS3d plugin was used in conjunction with Google SketchUp to simulate the dynamic flow of thermal energy inside the zones indicated by the yellow surfaces. The purple surfaces represent the shading objects (Parapets) while, blue surfaces represent doors and windows. The building has been divided into nine zones based on the type of activity.

(a)

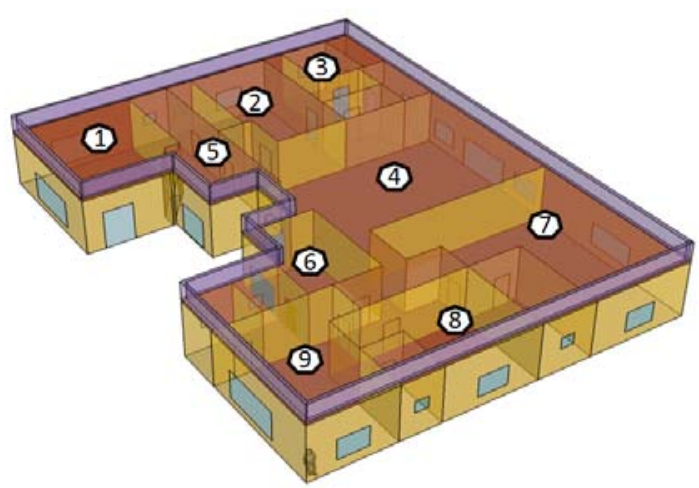

(b)
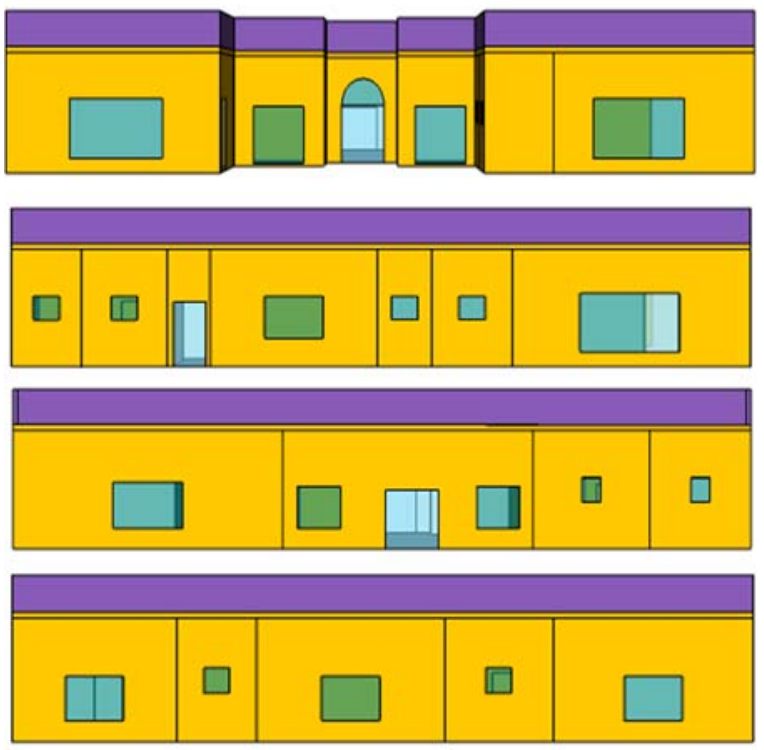

Figure 2. Sketched model using Google SketchUpTM (a) Villa sections with zone numbers (purple surfaces represent the shading objects (Parapets) while, blue surfaces represent doors and windows. (b) Orientation of villa cross-sectional views from top to bottom: South-West, North-West, North-East and South-East.

The sketched model of the building is imported into TRNSYS workplace to conduct the energy analysis for four different building scenarios which are basecase, ASHRAE, LEED and Estidama villa cases. Table 4 provides a summary of specifications for each building scenario to be analyzed.

It is noticeable that Estidama has the lowest U-Value for walls and roof while it has a moderate U-Value for windows and Solar Heat Gain Coefficient (SHGC) value. The majority of the buildings that were built before 2010 is still using Incandescent lightings, therefore, this option was selected to be within basecase specification. 
Table 4. Summary of specification for Base-Case, Estidama, LEED and ASHRAE

\begin{tabular}{|c|c|c|c|c|}
\hline & $\begin{array}{c}\text { Basecase } \\
{[20]}\end{array}$ & $\begin{array}{c}\text { Estidama (RE-R1) } \\
{[21]}\end{array}$ & $\begin{array}{l}\text { LEED } \\
{[22]}\end{array}$ & $\begin{array}{c}\text { ASHRAE 90.2-2007 } \\
{[23]}\end{array}$ \\
\hline \multicolumn{5}{|c|}{ Envelop Requirements } \\
\hline \multicolumn{5}{|c|}{ External walls } \\
\hline $\mathrm{U}$ value $\mathrm{W} \cdot \mathrm{m}^{2} \cdot \mathrm{K}^{-1}$ & 2.32 & 0.32 & 0.45 & 0.38 \\
\hline Absorption & 0.50 & 0.50 & 0.50 & 0.50 \\
\hline \multicolumn{5}{|c|}{ Roof } \\
\hline $\mathrm{U}$ value $\mathrm{W} \cdot \mathrm{m}^{2} \cdot \mathrm{K}^{-1}$ & 0.54 & 0.14 & 0.31 & 0.30 \\
\hline Absorption & 0.20 & 0.20 & 0.20 & 0.20 \\
\hline \multicolumn{5}{|c|}{ Glazing } \\
\hline $\mathrm{U}$ value $\mathrm{W} \cdot \mathrm{m}^{2} \cdot \mathrm{K}^{-1}$ & 6.00 & 2.20 & 1.68 & 3.80 \\
\hline SHGC & 0.86 & 0.40 & 0.23 & 0.37 \\
\hline \multicolumn{5}{|c|}{ Air conditioning } \\
\hline EER & 14.5 & & & \\
\hline \multicolumn{5}{|c|}{ Lighting Requirements } \\
\hline Type of bulb & Incandescent & Fluorescent & Fluorescent & Fluorescent \\
\hline Controller type & N/A & \multicolumn{3}{|c|}{ Power fraction control } \\
\hline Lighting Profile & \multicolumn{3}{|c|}{ Based on Estidama lighting profile } & \\
\hline \multicolumn{5}{|c|}{ Domestic Hot Water Requirements } \\
\hline L/person/day & $50 \mathrm{~L}$ & $50 \mathrm{~L}$ & $50 \mathrm{~L}$ & \\
\hline Water Profile & \multicolumn{4}{|c|}{ Based on ASHRAE 60.2 standard } \\
\hline
\end{tabular}

\section{Model Development}

This section demonstrates TRNSYS model development in terms of building systems such as Air conditioner, Lighting and Electric water heating. The simulation was run for a 1 year time period with 5 mins time step. The weather data Type15 represents TMY2 for Abu Dhabi. The building component Type 56 requires a detailed information on the envelop materials which was provided in Table 2.

As Figure 3 shows, air conditioner unit and thermostat controllers are added. Weather data are fed into building for each corresponding zone. The indoor temperature and relative humidity in each zone are connected to AC Type651 and a differential controller for indoor temperature is used with a cooling setpoint of $24^{\circ} \mathrm{C}$ and 0.5 deadbands. Indoor temperature, humidity, comfort levels and power required of each zone are monitored. The results are reported as: indoor temperature and relative humidity, PMV/PPD, monthly building loads and AC power, Sensible Heat Ratio (SHR), Energy Efficiency Ratio (EER) and Coefficient of Performance (COP) of the AC.

Lighting Schedule Type 14d is defined according to Estidama lighting profiles which are provided in Figure 4 for the nine zones of the building. The fraction of light is then multiplied by the number of lights in each zone to give an estimation of total monthly consumption for each zone

Figure 5 shows TRNSYS components used to simulate the electric water heating system. Water profile Type 1243a is based on ASHRAE recommended usage factor of water. The flow rate of water is assumed to enter a diverter that routes the mains water directly to the water tank or to the load by a Tee-piece (Mixer) junction. A Tee-Piece valve mixes the cold water coming from the mains water with the hot water coming from the tank. Afterward, the load temperature is monitored and heater energy consumption results are obtained. 


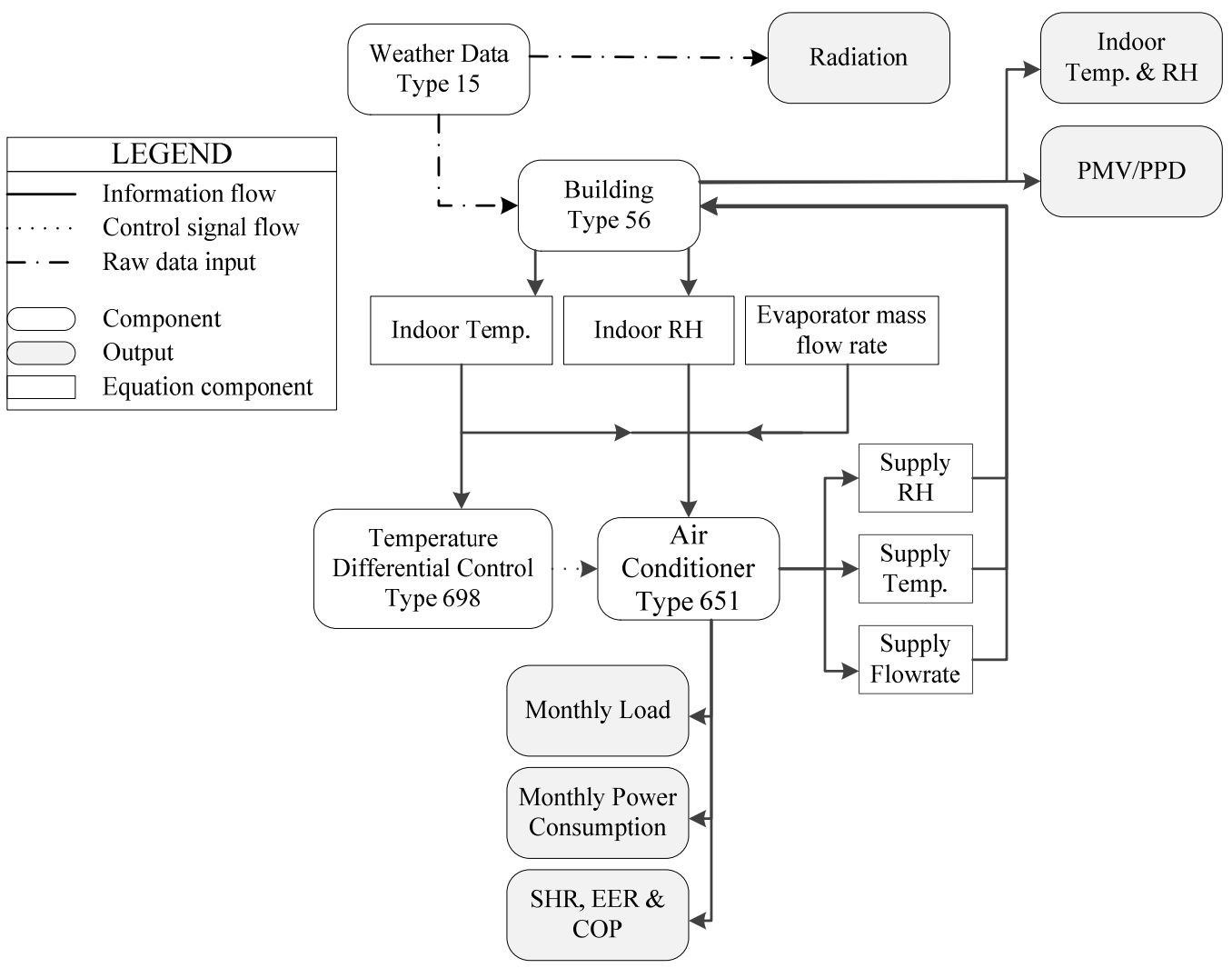

Figure 3: Simulation of air conditioned space (villa) in TRNSYS

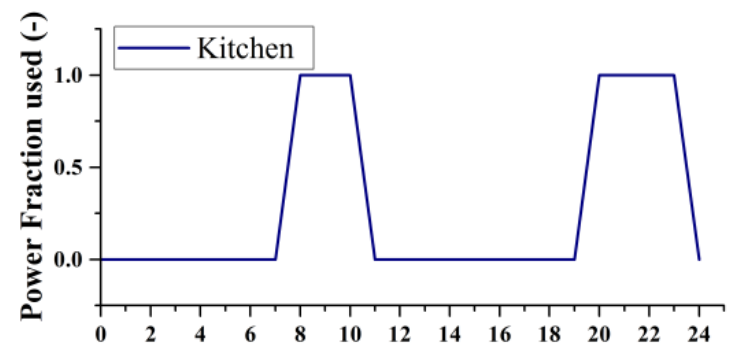

TIME (hr)

$$
\text { I }
$$

0.6

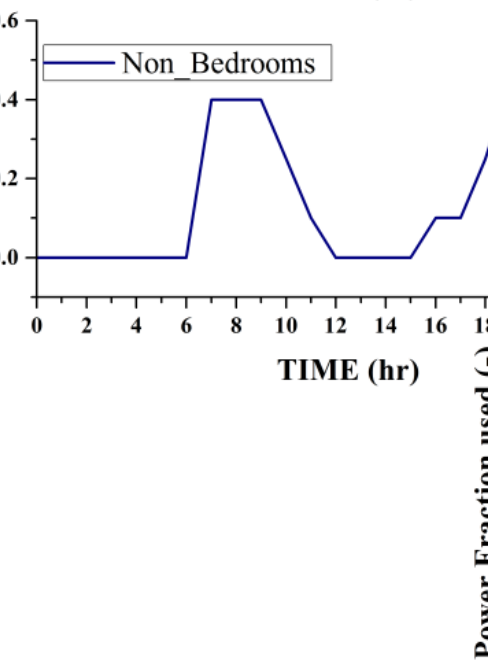

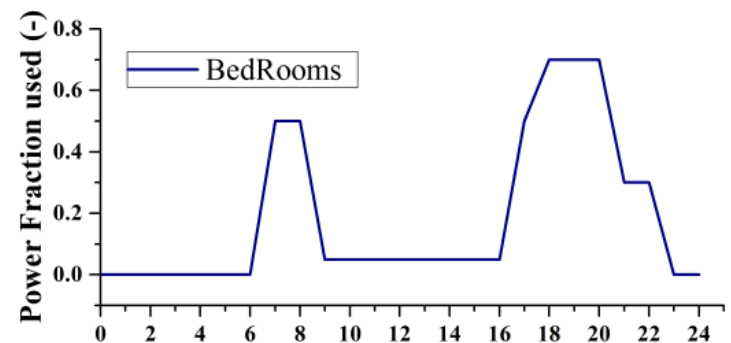

TIME (hr)

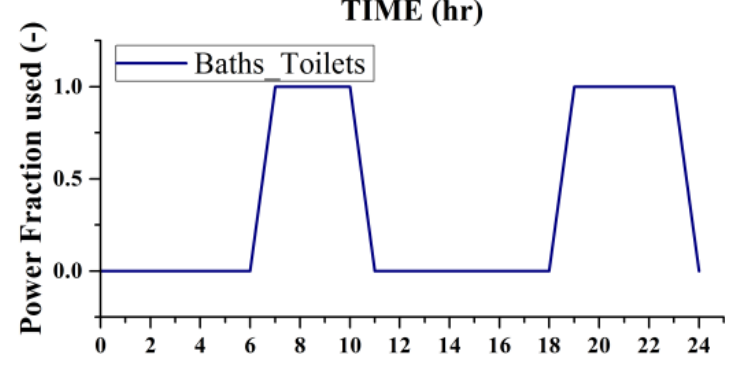

TIME (hr)

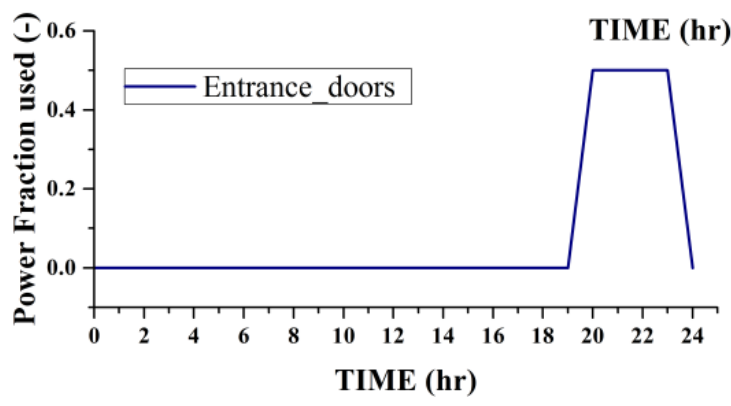

Figure 4: Estidama lighting Schedule for villa internal lightings loads [24] 


\section{Results and Discussion}

The simulation was run for four cases: Basecase, Estidama, LEED and ASHRAE 90.2 with 5 mins time step. This section dicusses the building electricity consumption and thermal comfort analysis of the four cases.

\subsection{Building Electrical consumption}

The electrical consumption of the building is comprised of different systems such as, air conditioner, lightings and electric water heaters. At the end, a summary of total energy consumption will be provided and compared against each building case scenario.

\subsubsection{AC electricity consumption}

Zones indoor temperature: The indoor temperature of each zone was controlled using a differential controller with cooling setpoint at $24^{\circ} \mathrm{C}$, heating setpoint of $20^{\circ} \mathrm{C}$, and deadband 0.5 . The results showed that, the indoor temperature of each zone falls within the controller range, however, zones 3 and 9 showed a sensitive behavior toward the temperature change. The reason could be that zone 3 has small area with 1 ton AC, i.e. oversized AC.
Zones humidity: Humidity ratio for each zone is represented in Figure 6, it is noticable that zones humidity ratio falls within the recommended limit of $0.008 \sim 0.012 \mathrm{~kg}_{\mathrm{w}} / \mathrm{kg}_{\mathrm{a}}$ most of the time.

Figure 7 (a) compares between the four building scenarios which is Basecase, ASHRAE, LEED and Estidama in terms of monthly sensible and latent required loads for the total building. It shows that heating is required during the winter season mainly during January, February, and December, while there is a keen demand for cooling requirements during the summer period, i.e., July and August. Latent cooling demand also increases during summer seasons due to the high outdoor humidity ratio. That is because as air temperature increases, the air capacity to hold moisture increases. In contrast, latent energy is very low during winter season; as a result, heating is required to maintain a certain level of relative humidity to meet the comfort level for the occupant. It is noticeable that, there is a considerable reduction in total energy while applying Estidama villa specifications. Figure 7 (b) shows the annual energy utilization intensity (EUI) of the building for each case scenario. It shows that applying these rating systems for residential buildings in Hot and Humid climate will result in dramatic reduction in the requirement of the cooling. Estidama required the least sensible energy compared to the other rating systems while it is also noticeable that there is a minimum difference between ASHRAE and LEED.

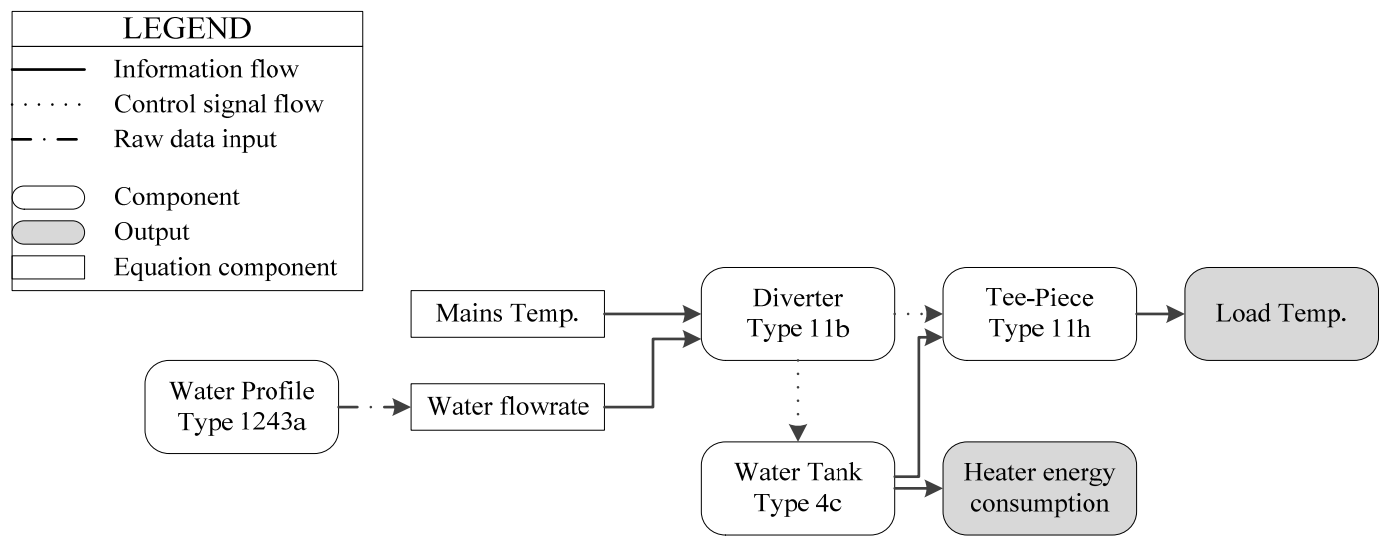

Figure 5: Electric water heating system in TRNSYS

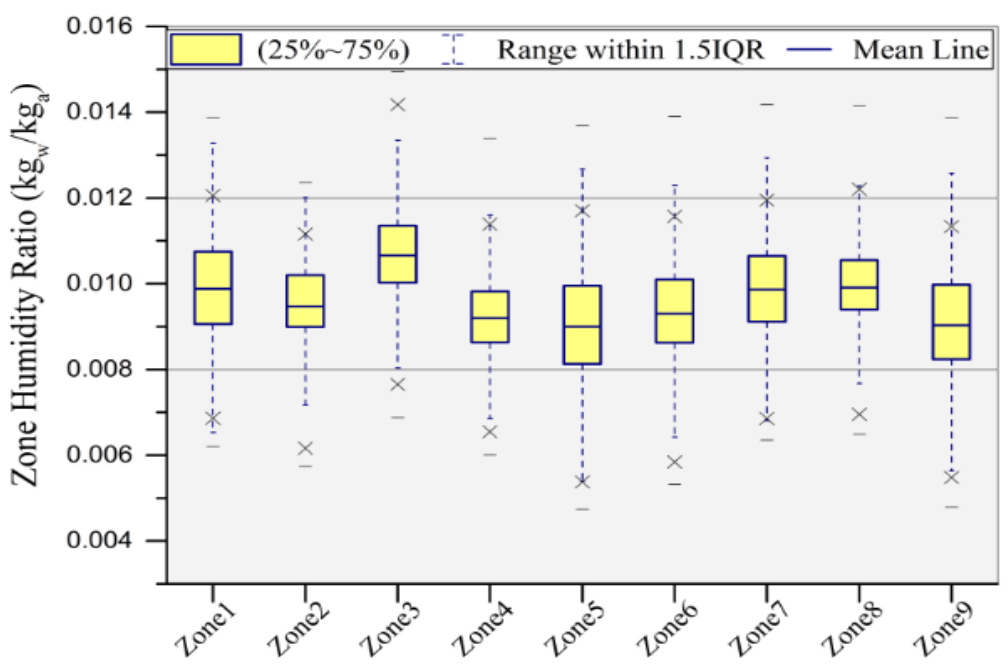

Figure 6: Hourly indoor humidity ratio for each zone (Time step=5mins) 


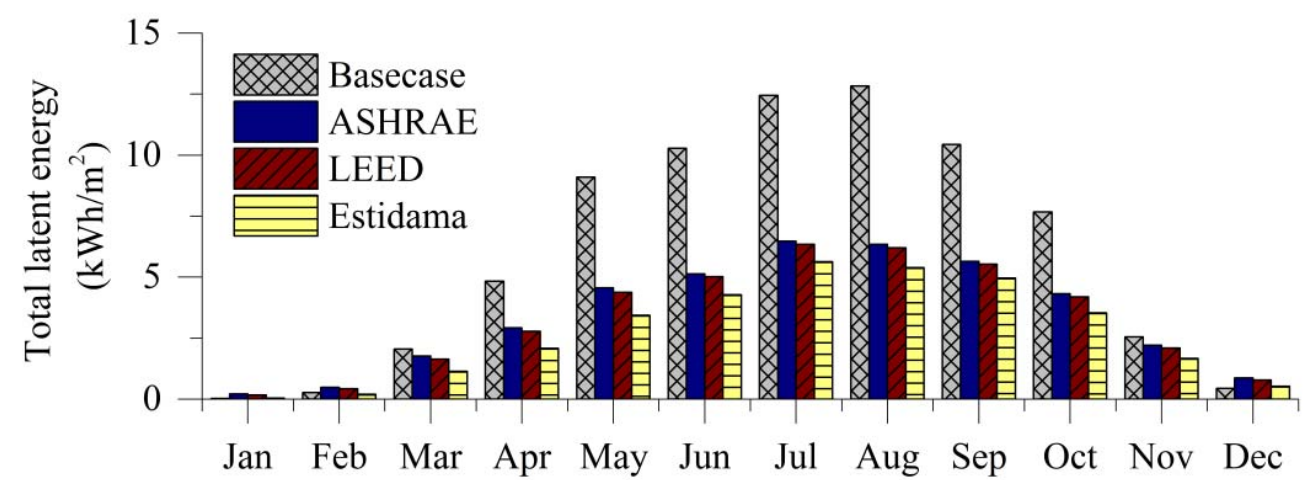

(a)

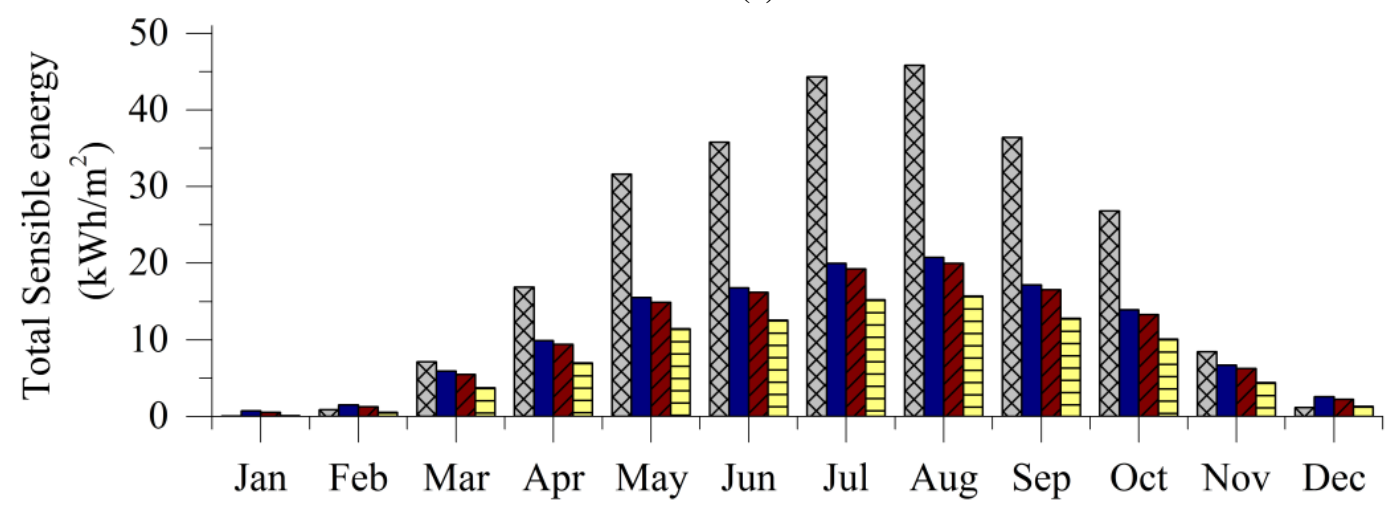

(b)

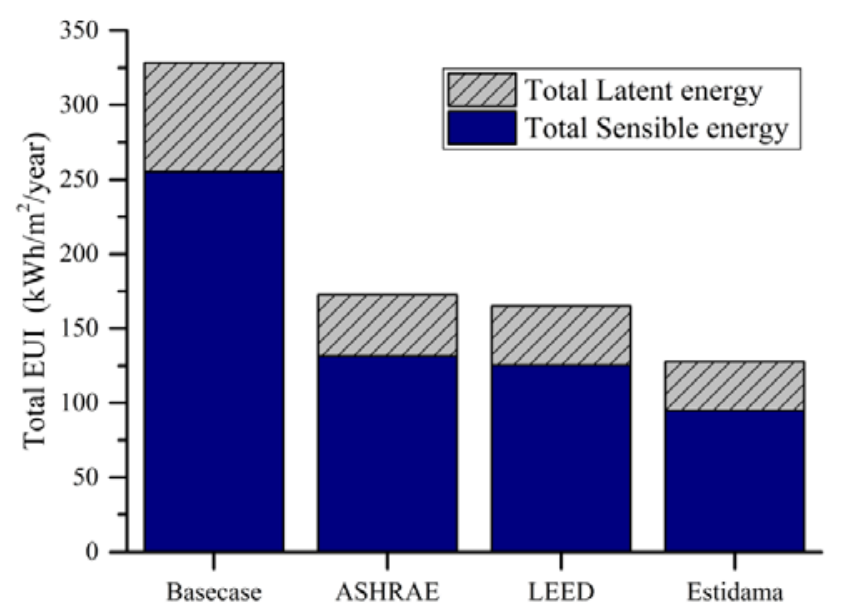

(c)

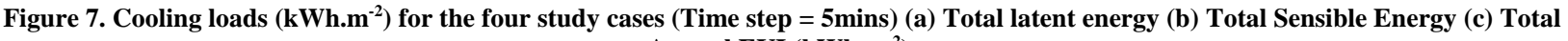
Annual EUI (kWh.m ${ }^{-2}$.

The Room Sensible Heat Ratio (RSHR) is also calculated using Eq.(1). The RSHR represents the ratio of the room sensible load to the room total load and it is an essential calculation to estimate the proper size of air condition system.

$$
R S H R=\frac{\text { Room sensible load }}{\text { Room (sensible }+ \text { latent }) \text { loads }}
$$

Figure 8 shows average SHR for the four cases studied; A lower RSHR value indicates a high insulated building with less sensible cooling energy demand, therefore, lower AC size. It shows that the average AC SHR will not meet the cooling demand of the four cases since it has a lower SHR value $(0.73 \sim 0.76)$ than the required room SHR. It can also indicate an increase in the latent load gains. This is illustrated by Figure 7, by which the dehumidification requirement was increased from 24\% (LEED and ASHRAE) to 27\% (Estidama). The air conditioning system sensible heat ratio should match the characteristics of the RSHR in order to ensure that the selected air conditioning system would be able to accommodate the air conditioning loads. Failure to do so would lead to many known building issues in hot and humid regions such as, mold and condensation. 


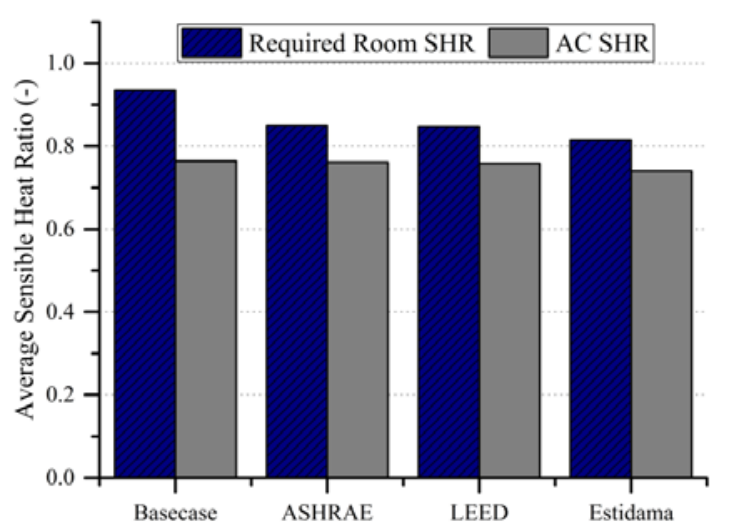

Figure 8. Comparison of Building average SHR requirements and AC SHR provided $($ Time step $=5$ mins $)$

Figure 9 shows the monthly total AC energy consumption for both Estidama and Basecase scenarios. It is obvious clear that during summer, the cooling demand will be higher, because of higher ambient temperature and longer days than in winter.

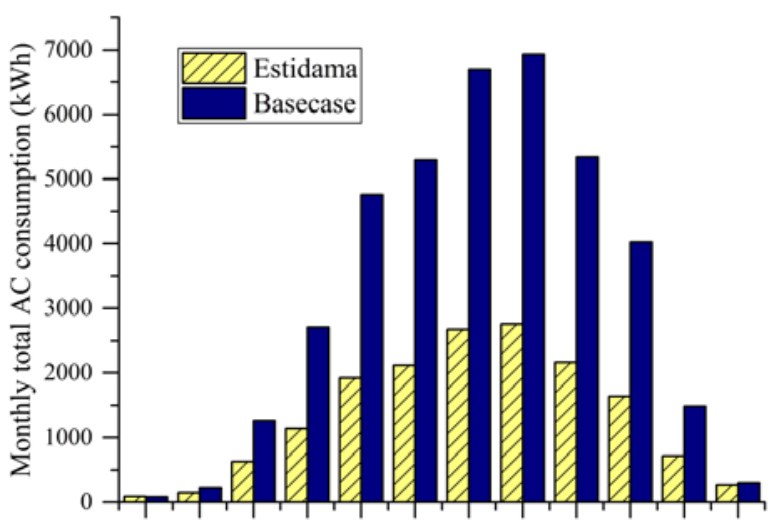

Jan Feb Mar Apr May Jun Jul Aug Sep Oct Nov Dec

Figure 9. Comparison of monthly total AC energy consumption between Basecase and Estidama (Time step $=5 \mathrm{mins}$ )

Figure 10 shows the annual total AC consumption of each case. Estidama has the lowest AC consumption among all $(13,906$ $\mathrm{kWh}$ ) due to higher insulation requirements for the walls, roof and windows. The annual average EER value for the system is 14.5.

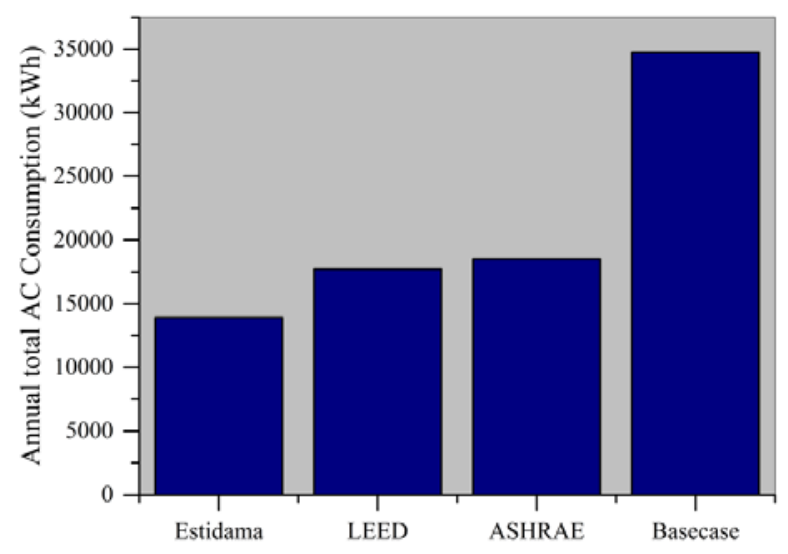

Figure 10. Annual total AC consumption for Basecase, Estidama and ASHRAE (Time step $=5 \mathrm{mins})$

\subsubsection{Lighting}

Incandescent lights are in use in old villas which are constructed 10 20 years ago. Newly constructed villas are recommended to use Fluorescent lights instead of the old Incandescent which consumes $75 \%$ more than Fluorescent lights for the same lighting density unit. The result in Figure 11 shows that, an energy saving of $9000 \mathrm{kWh}$ is possible when using energy efficient lights such as Fluorescent lights.

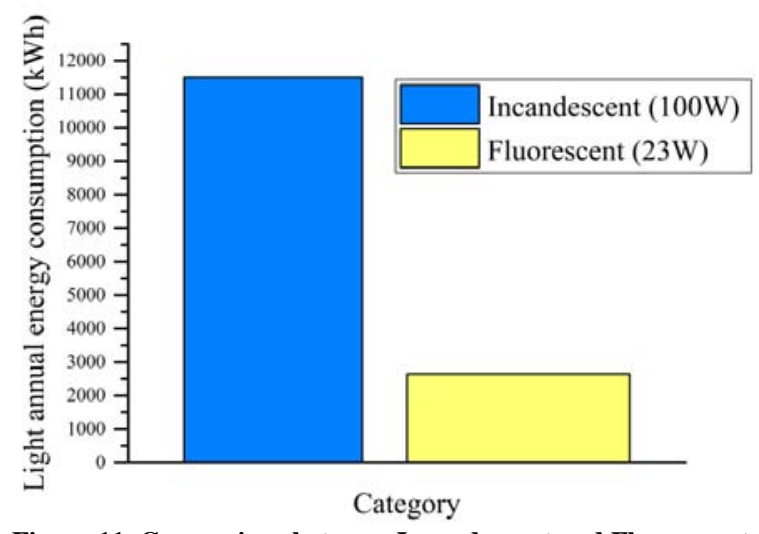

Figure 11. Comparison between Incandescent and Fluorescent lights annual energy consumption

\subsubsection{Domestic Hot Water}

Electric water heating is the most common approach used in residential buildings in the U.A.E. The electric water heating system mainly consists of a tank and one or two electric heating elements depending on tank size.

In order to accommodate the hot water load, one has to take into consideration the size and temperature of the water tank. ASHRAE 90.2-2007, has recommended a temperature of $60^{\circ} \mathrm{C}$ in order to prevent the growth of bacteria which is responsible for Legionnaires' disease as well as reducing the risk of scalding. Such high temperature should be installed with tempering valve. However, most buildings wasn't equipped with a tempering valve, therefore, they normally have a hot water temperature between $40 \sim 50^{\circ} \mathrm{C}$. Therefore, special care should be taken since this low temperature of water can be an environment for Legionella bacteria. In this simulation, a tempering valve was considered and the hot water temperature was set to $60^{\circ} \mathrm{C}$. Water daily consumption was assumed to follow ASHRAE water consumption profile and a tank size of $300 \mathrm{~L}$ (50L/person/day) was considered. Other parameters are summarized in Table 5. The results showed that, an annual heating rate of $3386 \mathrm{kWh}$ is required.

Table 5: Electric water heating system specifications

\begin{tabular}{lcc}
\hline Specification & Value & Units \\
\hline \hline Water profile & Based on ASHRAE & $\mathrm{kg} / \mathrm{hr}$ \\
& $90.2-2007$ & \\
Inlet water temperature & 25.6 & ${ }^{\circ} \mathrm{C}$ \\
Tank Volume & 0.3 & $\mathrm{~m} 3$ \\
Tank loss coefficient & 3 & $\mathrm{~kJ} / \mathrm{hr} \cdot \mathrm{m}^{2} . \mathrm{K}$ \\
$\begin{array}{l}\text { Number of heating } \\
\text { elements }\end{array}$ & 2 & \\
$\begin{array}{l}\text { Maximum heating rate } \\
\text { for elements 1\&2 }\end{array}$ & 4 & $\mathrm{~kW}$ \\
\hline
\end{tabular}

\subsubsection{Summary of the results}

The summation of the electric energy consumption of the different systems is represented in Table 6 below. Figure 12 depicts the total annual EUI consumption of each building scenario and it shows that Estidama consumed the least energy due to better insulation, more efficient windows, lighting and ACs. Figure 12 also shows the percentage consumption of each 
system for the four building scenarios. It also shows that using efficient lightings results in a major reduction in total energy consumption. Domestic water heating system contributed to $13.61 \%$ of the total energy consumption. Such energy can be further reduced using solar water heating system.

Table 6. Summary of electric energy consumption by different building's systems

\begin{tabular}{lcccc}
\hline Category & $\begin{array}{c}\text { Base } \\
\text { Case } \\
(\mathrm{kWh})\end{array}$ & $\begin{array}{c}\text { ASHRAE } \\
(\mathrm{kWh})\end{array}$ & $\begin{array}{c}\text { LEED } \\
(\mathrm{kWh})\end{array}$ & $\begin{array}{c}\text { Estidama } \\
(\mathrm{kWh})\end{array}$ \\
\hline $\mathrm{AC}$ & 34,718 & 18,501 & 17,714 & 13,906 \\
Lighting & 11,500 & 2500 & 2500 & 2500 \\
$\begin{array}{l}\text { Electric } \\
\text { water } \\
\text { heating }\end{array}$ & 3386 & 3386 & 3386 & 3386 \\
\hline Total & 49,604 & 24,387 & 23,600 & 19,792 \\
\hline
\end{tabular}

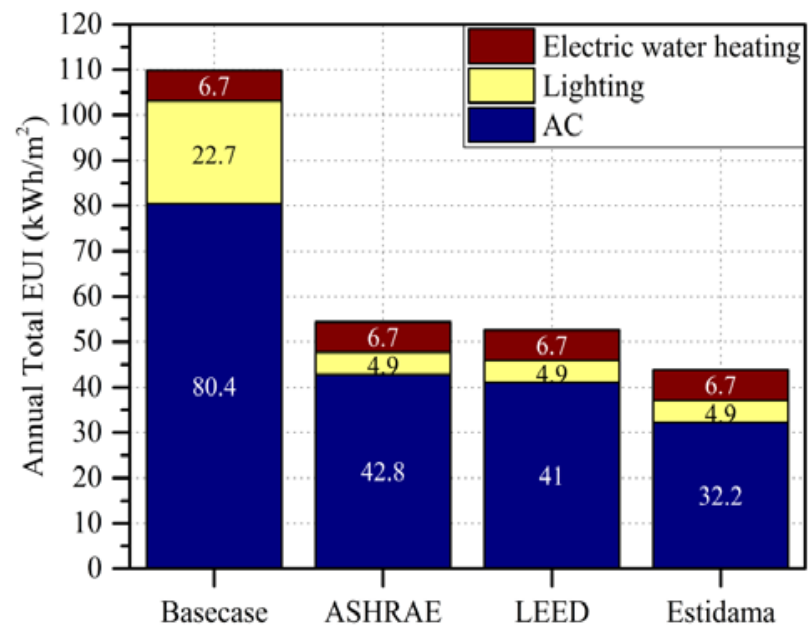

Figure 12: Annual total EUI for different building scenarios

\subsection{Thermal comfort analysis}

Thermal comfort is defined by a combination of six parameters which are indoor air temperature, mean radiant temperature, air speed, relative humidity, metabolic rate, and clothing insulation. The study of thermal comfort analyzes the sensation of the occupant to the thermal changes inside the zone. Generally, PMV/PPD model is used to predict this sensation and the recommended limit is $(-0.5<\mathrm{PMV}<+0.5)$. The comfort type defined in TRNSYS software is based on EN ISO 7730 standard which considers the parameters listed in Table 7. However, the influence of direct or diffuse solar radiation was not taken into account by the software for PMV/PDD calculation.

Table 7: Thermal comfort parameters

\begin{tabular}{lcc}
\hline \multicolumn{1}{c}{ Parameter } & Description & Value \\
\hline \hline Relative velocity & - & $0.1 \mathrm{~m} / \mathrm{s}$ \\
Metabolic rate & Seated, Relaxed & $1 \mathrm{met}$ \\
Clothing insulation & Light clothes & $1 \mathrm{clo}$ \\
External work & - & 0 met \\
\hline
\end{tabular}

Figure 13 demonstrates the hourly average PMV result for zone 4 of the building in which it reveals that Estidama is the most appropriate and comfortable rating system to be used for residential buildings in hot and humid climate. Still, Estidama needs further improvements to bring the limits of the PMV within the acceptable range recommended by ASHRAE Standard $55(-0.5<\mathrm{PMV}<+0.5)$. The results of the remaining zones also showed that using Estidama leads to the least energy consumption and most comfortable indoor conditions.

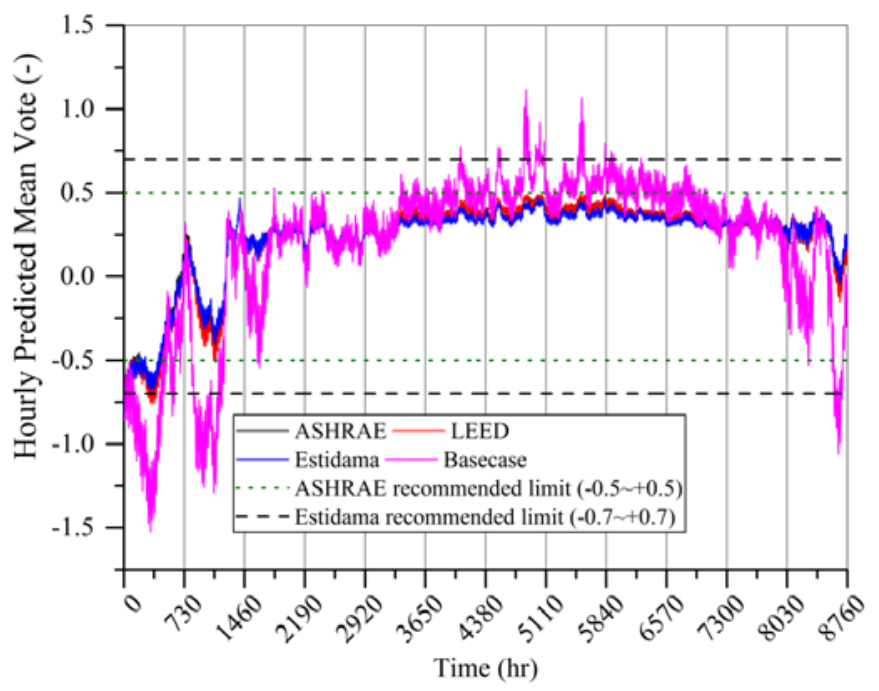

Figure 13. Thermal comfort analysis for one zone of the villa, $($ Time step $=5 \mathrm{mins})$

Figure 14 analyzes the comfort level of Estidama house for all the conditioned zones for 1 year simulation time. It can be seen that, all the zones meets Estidama requirement (PMV: -0.7 0.7: Blue line, $\mathrm{PPD}<15 \%$ ) for comfort rating while Zone 1 couldn't meet ASHRAE 55 standard requirements for comfort (-0.5 0.5: Red line).This could be due to the high temperature variation in this zone because it is oriented toward south-west in which it gets more solar radiation than other zones, therefore, it demands more cooling. Figure 15 shows ASHRAE 55 recommended comfort zones for indoor environment. The data included corresponds to the 9 zones of the villa in which it fall within the comfort zones. However, red dotted represent zone 3 of the villa in which it lies in the west orientation of the villa. It is noticeable that some of the time in the year, it experiences cold room temperature and that is due to several reasons such as: sun altitude with respect to the room orientation, small size room $\left(11 \mathrm{~m}^{2}\right)$, therefore, it requires less than 1 ton $\mathrm{AC}$. 


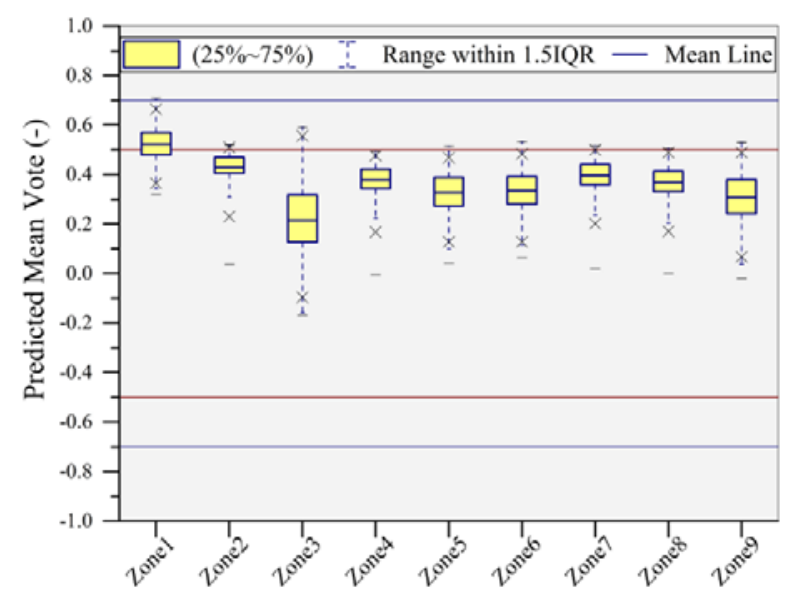

(a)

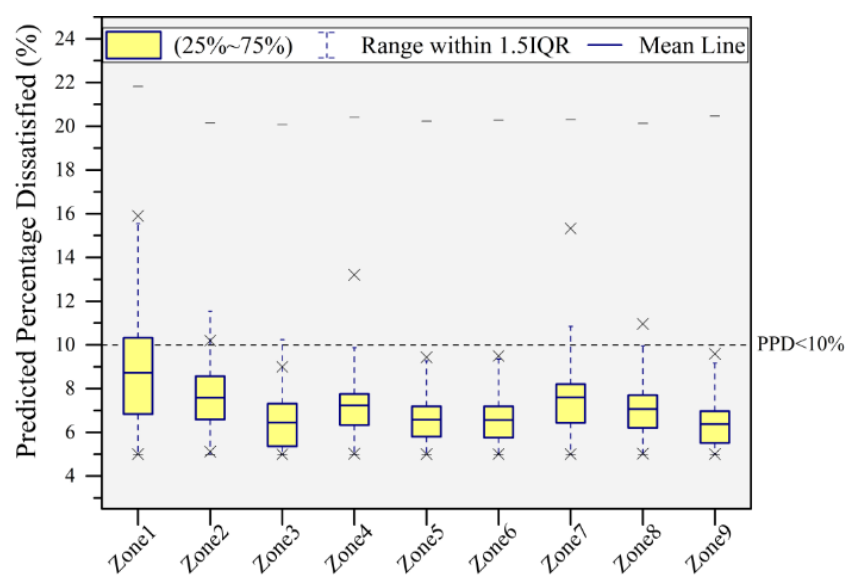

(b)

Figure 14. PMV/PPD Analysis for Estidama for 8760hrs, (Time step = 5mins) (a) Predicted Mean Vote (b) Percentage of Dissatisfaction

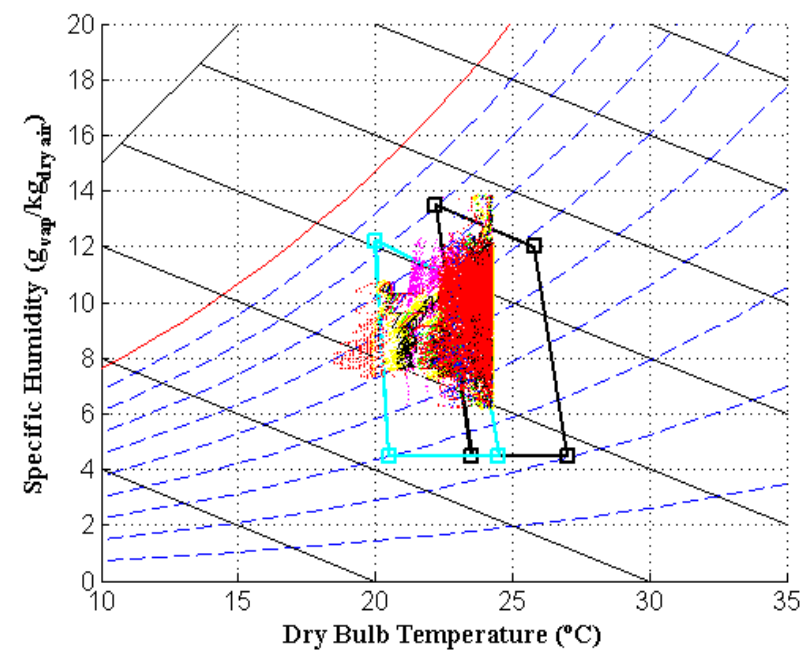

Figure 15. Indoor conditions of all zones for Estidama villa with ASHRAE comfort zone, $($ Time step $=5$ mins)

\section{Environmental Impacts}

One of the techniques to assest the environmental impact of an energy generation and consumption is to evaluate its entire life cycle in terms of extraction and transporation of raw materials, manufacturing, installation, service life and recycling and disposal.

As Figure 16 shows, U.A.E has the highest $\mathrm{CO}_{2}$ emission per capita compared to Saudi Arabia and United State. However, there is a reduction in $\mathrm{CO}_{2}$ emissions compared to 2003. It is also noticable that Saudi Arabia has an increased level of $\mathrm{CO}_{2}$ emissions over the years and that could be due to the new development processes that are currently undergoing in Saudi Arabia.

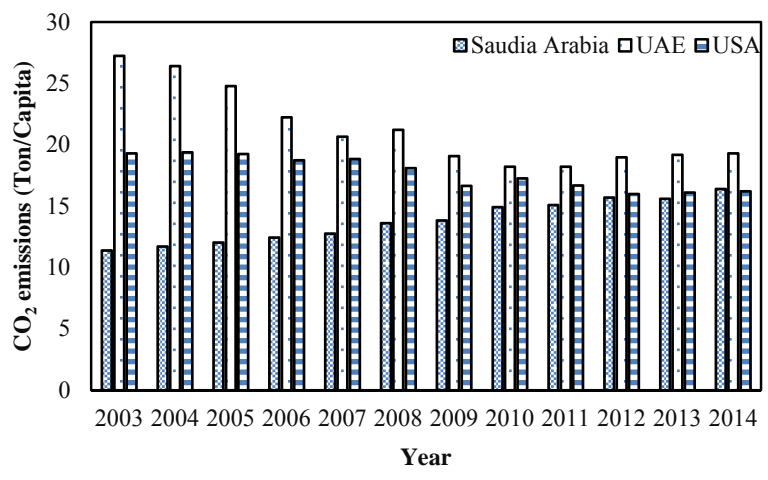

Figure 16. History of $\mathrm{CO}_{2}$ emissions for Saudi Arabia, United Arab Emirates and United States (2000-2014) [25]

By analyzing the current conditions of $\mathrm{CO}_{2}$ emissions around the world, it will be possible to study different alternatives to reduce $\mathrm{CO}_{2}$ emission for the corrosponding high emission countries and promote more clean technologies to offest such emissions. It is noticable from Figure 17 that the highest countries according to $\mathrm{CO}_{2}$ emissions per capita are United Arab Emirates, Luxemburg, United state, Australia and Canada.

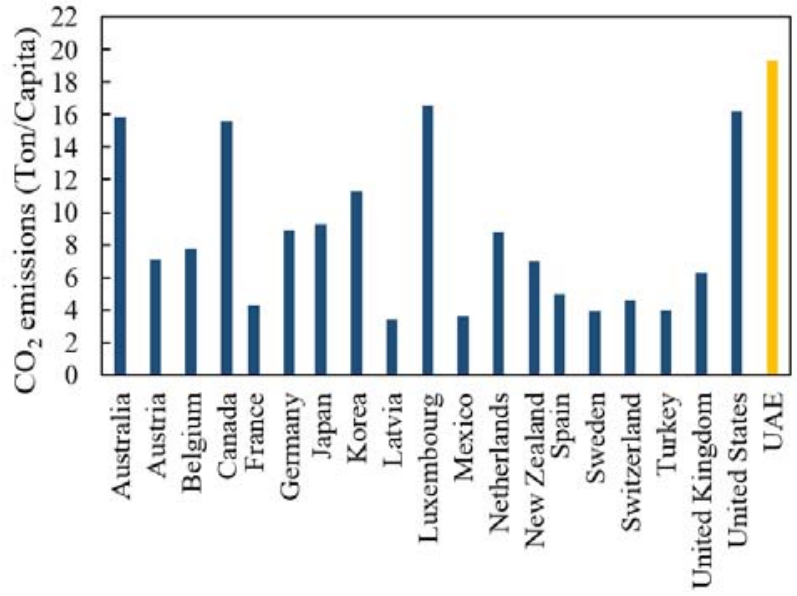

Figure 17. $\mathrm{CO}_{2}$ emissions per capita for various $\mathrm{OECD}$ countries and UAE in 2014 [25] 
Currently, actions are taken by U.A.E to move toward sustainable and healthy environments by applying new policies such as Feed-in-Tarrifs and reducing government subsidizing cost of electricity. Therefore, it is anticipitated by 2030 that U.A.E can achieve a considerable reduction in terms of $\mathrm{CO}_{2}$ emissions. One of the important developments in U.A.E, specifically in Abu Dhabi is the implementation of Estidama building codes. The result of this paper highlighted that $60 \%$ of annual energy reduction relative to the base-case villa was achieved while applying Estidama code. This reduction in electricity consumption can be further illustrated by reduction in $\mathrm{CO}_{2}$ emissions.

Natural gas is mostly used in the U.A.E to generate electricity. The $\mathrm{CO}_{2}$ emissions associated with combusting natural gas for electricity consumption by a household can be estimated using the following equation:

$$
\mathrm{CO}_{2} \text {, Production }=C \times E_{\text {consumption }}
$$

where $\mathrm{C}$ represents fuel $\mathrm{CO}_{2}$ emission coeffient which is 0.18 $\mathrm{kgCO}_{2} / \mathrm{kWh}$ for Natural gas [26] and Econsumption represent the energy consumed by end-user. Therefore, Figure 18 shows that applying Estidama building specification resulted in annual avoided $\mathrm{CO}_{2}$ emissions of $7013.16 \mathrm{Kg}$ (7.01 ton).

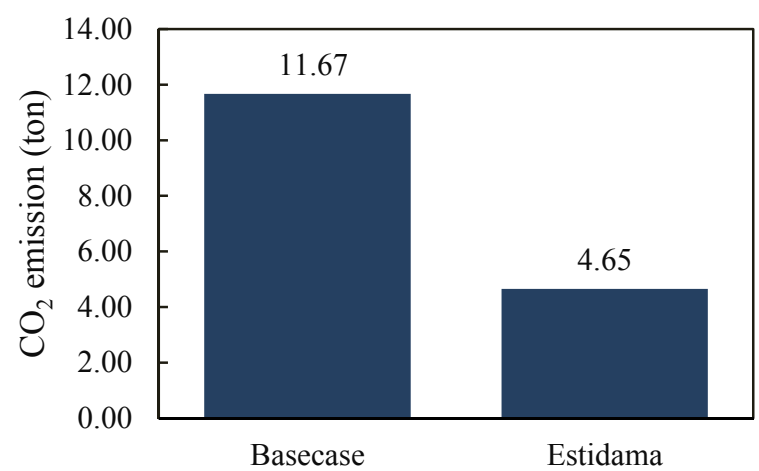

Figure 18. Total Annual $\mathrm{CO}_{2}$ emissions for Basecase and Estidama villas based on home electricity consumption (Total annual electricity consumption for Basecase: $109.8 \mathrm{kWh} / \mathrm{m}^{2}$, and Estidama : $43.8 \mathrm{kWh} / \mathrm{m}^{2}$, Area: $506 \mathrm{~m}^{2}$ )

\section{Conclusion}

This paper analyzes the energy performance and thermal comfort of a single-family house under four different building performance scenarios which are Estidama, LEED, and ASHRAE 90.2 as well as a base case as built specifications and investigates their applicability to Abu Dhabi climate. Transient System Simulation (TRNSYS) program was selected to perform a detailed energy analysis of the building for the four different scenarios. The results showed that a significant decrease in energy, about $61 \%$, was achieved when applying Estidama codes due to better insulation, more efficient windows, lighting and ACs compared to the other building codes. Thermal comfort analysis revealed that Estidama is the most appropriate and comfortable rating system to be used for residential buildings in hot and humid climate. In spite of that, Estidama needs further improvements to bring the limits of the PMV within the acceptable range recommended by ASHRAE Standard 55 ($0.5<\mathrm{PMV}<+0.5$ and PPD $<10 \%$ ). Moreover, by conducting environmental analysis, it was shown that 7 tons of $\mathrm{CO}_{2}$ was avoided while applying Estidama building specifications.

\section{References}

[1] L. Pérez-Lombard, J. Ortiz, and C. Pout, "A review on buildings energy consumption information," Energy and Buildings, vol. 40, pp. 394-398, 2008/01/01/2008.

2] H. F. Castleton, V. Stovin, S. B. M. Beck, and J. B. Davison, "Green roofs; building energy savings and the potential for retrofit," Energy and Buildings, vol. 42, pp. 1582-1591, 2010/10/01/2010.

[3] S.-E. Ouldboukhitine, R. Belarbi, I. Jaffal, and A. Trabelsi, "Assessment of green roof thermal behavior: A coupled heat and mass transfer model," Building and Environment, vol. 46, pp. 2624-2631, 2011/12/01/2011.

[4] I. Jaffal, S.-E. Ouldboukhitine, and R. Belarbi, "A comprehensive study of the impact of green roofs on building energy performance," Renewable Energy, vol. 43, pp. 157-164, 2012/07/01/ 2012.

[5] L. Aditya, T. M. I. Mahlia, B. Rismanchi, H. M. Ng, M. H. Hasan, H. S. C. Metselaar, et al., "A review on insulation materials for energy conservation in buildings," Renewable and Sustainable Energy Reviews, vol. 73, pp. 1352-1365, 2017/06/01/ 2017.

[6] L. E. Juanicó and A. D. González, "Thermal insulators with multiple air gaps: Performance, cost and embodied impacts," Journal of Building Engineering, vol. 12, pp. 188-195, 2017/07/01/ 2017.

[7] C. Feng, H. Zheng, R. Wang, X. Yu, and Y. Su, "A novel solar multifunctional PV/T/D system for green building roofs," Energy Conversion and Management, vol. 93, pp. 63-71, 2015/03/15/ 2015.

[8] S. K. Chou, K. J. Chua, and J. C. Ho, "A study on the effects of double skin façades on the energy management in buildings," Energy Conversion and Management, vol. 50, pp. 2275-2281, 2009/09/01/ 2009.

[9] G. Pérez, L. Rincón, A. Vila, J. M. González, and L. F. Cabeza "Behaviour of green facades in Mediterranean Continental climate," Energy Conversion and Management, vol. 52, pp. 1861 $1867,2011 / 04 / 01 / 2011$.

[10] S. Madureira, I. Flores-Colen, J. de Brito, and C. Pereira, "Maintenance planning of facades in current buildings," Construction and Building Materials, vol. 147, pp. 790-802, 2017/08/30/ 2017.

[11] P. Smealle, "Building occupant and customer satisfaction survey results for 2001," Proceedings of the General Services Administration, Public Building Service Workshop on Building Occupant and Customer Satisfaction, 2003.

[12] U. D. o. Energy, "Typical meteorological year weather data (2) for Abu Dhabi."

[13] W. Whistler, "LEED and estidama; a reference guide to critical similarities and differences."

[14] A. D. U. P. Council. (2010, 25/12/2014). Estidama [Website]. Available: http://estidama.upc.gov.ae/

[15] G. R. Newsham, S. Mancini, and B. J. Birt, "Do LEED-certified buildings save energy? Yes, but...," Energy and Buildings, vol. 41, pp. 897-905, 8// 2009 .

[16] R. Komurlu, D. Arditi, and A. P. Gurgun, "Applicability of LEED's energy and atmosphere category in three developing countries," Energy and Buildings, vol. 84, pp. 690-697, 12// 2014

[17] O. Awadh, "Sustainability and green building rating systems: LEED, BREEAM, GSAS and Estidama critical analysis," Journal of Building Engineering, vol. 11, pp. 25-29, 5// 2017.

[18] B. Abu-Hijleh, A. Manneh, A. AlNaqbi, W. AlAwadhi, and A. Kazim, "Refurbishment of public housing villas in the United 
Arab Emirates (UAE): energy and economic impact," Energy Efficiency, vol. 10, pp. 249-264, April 012017.

[19] B. Software. (2017, 2nd May, 2015). Calculating Degree Days. Available: http://www.degreedays.net/calculation

[20] W. A. Friess, K. Rakhshan, T. A. Hendawi, and S. Tajerzadeh, "Wall insulation measures for residential villas in Dubai: A case study in energy efficiency," Energy and Buildings, vol. 44, pp. 26-32, 2012.

[21] Estidama. (2010). Estidama Villa U-value Calculator v1.1, 2-5 Pearl Projects - RE-2: Cool Building Strategies, Prescriptive Method [Excel].

[22] L. Workshop, "LEED Principles and Green Associate Study Guide," 2014.
[23] A. 90.2, "Energy-Efficient Design of Low-Rise Residential Buildings," 2007.

[24] Estidama. (2010, Jan. 20, 2014). PVRS Energy Model Template (1-5 Pearl Projects) : Lighting. Available: http://estidama.upc.gov.ae/pearl-rating-system-v10/pearl-villarating-system.aspx

[25] O. f. Economic. (2015, June 13, 2015). Air and climate. Available: https://data.oecd.org/air/air-and-ghg-emissions.htm

[26] U. S. E. I. Administration. (2013, June 13, 2015). Carbon Dioxide Emissions Coefficients. Available: http://www.eia.gov/environment/emissions/co2_vol_mass.cfm 